\title{
Trajectories of Solidarities in France Across Fields of Vulnerability
}

\author{
Manlio Cinalli and Maria Jimena Sanbueza
}

\section{INTRODUCTION}

Solidarity has come under heavy strain in Europe over the last decade, at the same time as the economic, social, and political crisis of 2008 has had a tremendous impact on the attitudes and behaviours of European citizens (Giugni and Grasso 2015). In the media, the crisis has often been discussed using footage depicting human despair. These images have included pictures of destitute unemployed people queuing outside soup kitchens or sleeping rough (Department for Communities and Local Government 2015), in the face of general indifference on the part of bystanders (Andersson and Sundin 2016; Darley and Latané 1968) or of refugees and their babies drowning in European waters due to the negligence of rescue officers, without altering the broad indifference of the general public. ${ }^{1}$ In Europe, appeals to human solidarity have also gone unheard at difficult moments like when Europe faced the threat of Grexit, or in the aftermath of the UK referendum on European membership (Berend 2016; Calhoune 2017). This widespread "desensitisation" (Arendt 1982; Wilde 2013) went so far that some commentators chose to refer to a handful of countries with very little direct responsibility for the global economic crisis as PIGS

M. Cinalli $(\bowtie) \bullet$ M. J. Sanhueza

Centre de Recherches Politiques de Sciences Po, Paris, France

(C) The Author(s) 2018

C. Lahusen, M. Grasso (eds.), Solidarity in Europe,

Palgrave Studies in European Political Sociology,

https://doi.org/10.1007/978-3-319-73335-7_9 
(Portugal, Ireland, Greece, and Spain), in a tendentious attempt to single out culprits (de la Dehesa 2006). Ultimately, the idea that solidarity-a notion which has had an essential influence on the emergence of a sense of European citizenship - may well have lost its importance has given rise to systematic criticisms of the European project (Dainotto 2007).

The possibility that Europe may have entered a new homo homini lupus era calls for further research on the topic of solidarity, in order to assess whether Europeans can still rely on solidarity as a community resource (Bourgeois 1896; Hanagan 1980; Hyman 1986), or whether they have fractured into different and dispersed archipelagos of special interests. Nowhere is an analysis of solidarity more crucial than in France, which in this respect seems to stand at a crossroads. Solidarity is one of the major pillars of the French constitutional ethos, an essential component of "Fraternity" (Fraternité), a notion symbolically portrayed in the revolutionary tricolour, and that plays a prominent part in the national anthem. In recent years, however, many public policies based on solidarity have been scrutinised, heavily criticised, and eventually restricted so as to shrink the country's welfare expenditure (Cinalli and De Nuzzo 2017).

This chapter approaches the study of solidarity in France by comparing three important vulnerable groups, namely, the disabled, the unemployed, and refugees. If we begin with the disabled, one notes that protection for the disabled has worsened in France, particularly if we consider the impact of public expenditure cuts and the reduction in the overall scope of government action. While public authorities do oversee a generous healthcare system, they only dedicate a minor fraction of its resources to disability policies, prompting increasing outcries from disability groups. In terms of the erosion of welfare entitlements, another group that has been massively affected are the unemployed, who have faced a significant decline in the amount of financial support made available to them and in their chances of being reinserted into the labour market (Chabanet 2014, 2017). Refugees, meanwhile, have been the target of many restrictive measures. This underscores how negative the agenda of successive French governments has been, both on the left and on the right, and this has deterred new arrivals and has made it difficult for citizens to show their solidarity with refugees while staying within the boundaries of the law (Müller 2009, 2014).

The way we approach solidarity in this chapter is quite comprehensive and hinges on an important distinction between two different meanings of solidarity: solidarity understood as an input and solidarity understood as 
an output. On the one hand, we focus on areas where solidarity expresses itself as a process, whether at the individual level of empathy with the vulnerable or at the political level through partaking within the republican community. On the other hand, we also consider the instances where solidarity expresses itself through one-off actions carried out by individuals at a specific time and place. In particular, we are attentive to the very varied nature of the repertoire of actions carried out by different individuals (Teorell et al. 2007), including when they act as part of a group (Tilly 1978). Our dual focus on solidarity as an input and as an output thus enables us to distinguish between various "trajectories of solidarity" and thereby to better understand the way certain individual variables (such as self-identification and proximity) combine with political variables (like voting, an interest in politics, or the reading of newspapers) in very different ways, to produce different configurations of solidarity actions in each of the three fields of vulnerability considered here.

Our first major goal in this chapter is to provide a detailed analysis of the way solidarity actions vary within and across the three fields of vulnerability analysed here. The second, more ambitious, goal of the present chapter is to search for the broad causes that could help to explain these variations in the nature of the solidarity actions carried out. In this specific instance, the distinction we establish between individually based and politically based solidarity trajectories makes it possible for us to determine whether solidarity actions are propelled more by self-identification and by a great degree of proximity between individuals in the private sphere, or whether they are the outcome of the republican process of transforming the "general will" into specific policies and laws through the mediation of public institutions. The chapter starts by presenting the three fields of vulnerability that are the focus of our analysis, and it outlines the theoretical foundations for choosing these groups in particular. We also focus on the difference between various solidarity actions (and thus on solidarity as an output) and on the two main trajectories that lead to this type of actions, one centred on the individual and one on communal republican processes (here solidarity is understood as an input). The following step consists in focussing on different degrees of solidarity and on the various forms solidarity takes across all three fields of vulnerability (section "The Different Repertoires of Solidarity Actions"), before moving on to examine the two main trajectories that inform solidarity actions (section "Explaining the Dynamics of Solidarity: Individual Closeness Versus Republican Citizenship"). Finally, we sum up our most important findings 
and identify some important challenges that need be tackled by future research on vulnerability and solidarity (section "Conclusion").

\section{Solidarity and Vulnerability: A Cross-Field Theoretical Framework}

Any study of solidarity in France must take a critical distance to the idealised picture of "Fraternity" (Fraternité) that is typically presented as an essential pillar of French republicanism. Undeniably France is a country where health standards and the provision state protection in cases of illness remain relatively high compared to other developed countries, where dismissed workers have often united with other vulnerable groups under the same banner, and where some children of refugees (and of migrants more generally) have achieved leading positions in the business world and also at the head of the state itself. ${ }^{2}$ Beyond this evidence however, we also know that the decreased protection offered by the state to various vulnerable groups and welfare retrenchment in general have been going on for a long while, an evolution which is bound to have had an impact on the meaning and practice of solidarity. Fraternity has increasingly become a fundamental value in words only, unable to prevent vulnerable groups from being marginalised. Fraternity has also become a somewhat fuzzy term with respect to its ontological content; and progressively, political references to solidarity as a "public" fundamental, an essential aspect of republican citizenship, have become few and far between, replaced by a more individual notion of solidarity understood as a private virtue.

In the case of the disabled, for instance, there has been a change for the worse both in terms of health policies and in terms of the protection offered to sick people, particularly when one takes into account policies designed to reduce public spending. Throughout the 2000s and the 2010s, disability aid has suffered regular cuts in spite of the outcries of major French disability groups. ${ }^{3}$ As regards the unemployed, contentious issues such as work activation, long-term unemployment, and social dumping have all featured prominently in the public debate throughout the 2000s and the 2010s, with huge protests having been organised to denounce an overly contractualist approach to welfare as well as the broader, supply-focused trend governing many EU policies. The conditions governing unemployment benefits have become more restrictive, the use of sanctions has increased, while the latest reform of the French labour 
market in 2016, the Loi Travail, has outlined a range of cases where employers are now entitled to resort to economic redundancy. Lastly, political developments throughout the 2000s and 2010s have also resulted in an increasingly restrictive stance, on the part of the French state, towards refugees. This restrictive response has led to many evictions as well as to the final closure of the "jungle", a refugee camp close to Calais; it has also resulted in the tough border controls implemented at the time of the "Arab Spring" and of the Syrian war, which effectively expressed a lack of solidarity with the large number of Tunisians and Syrians who were fleeing from slaughters and inhuman conditions. This hardline position has even led to coercive measures being enforced to punish "solidarity crimes" committed by individual activists, on the basis of article L622-1 of the CESEDA, the Code regulating the Arrival and Residence of Foreigners and the Right of Asylum (Müller 2009, 2014).

These developments across various fields of vulnerability in France call for a more systematic evaluation of the trajectories that lead to solidarity actions, solidarity being understood both as an input and as an output. As an output, we analyse solidarity by considering the various forms of solidarity action that French citizens carry out across the fields of disability, unemployment, and support for refugees. In so doing, we draw on some of the seminal literature that appeared between the end of the 1990s and the early 2000s, and that focused on "altruism" and on the concrete instances of mobilisation carried out by pro-beneficiaries on behalf of weak groups (Cinalli 2004; Giugni and Passy 2001; Simeant 1998), but which has not so far resulted in many empirical studies of a systematically comparative nature (see however Lahusen 2013; Baglioni and Giugni 2014). While social research on solidarity has developed over the last decade, it has tended to focus on attitudes, commitments, and norms, for example, in terms of social citizenship (Bellamy et al. 2006), readiness to share one's own resources with others (Stjerno 2012: 2), support for fiscal policies of redistribution (Rehm 2009), resilient cleavages within Europe (Delhey 2007), and the weakening of bonds between member states. What our specific focus on solidarity as an output should allow us to do is to shed light on solidarity actions that either reinforce or weaken the position of vulnerable groups.

While the following section focuses mostly on the importance of distinguishing between the various forms that the solidarity repertoire can take, the main point we wish to make here is that by looking at these configurations, we also want to trace them back to solidarity understood 
as an input. In so doing, we approach solidarity as an active force, which itself tends to change according to the context in which it expresses itself. More specifically, our ambition is to determine whether solidarity actions follow from (1) trajectories that originate in the private sphere and that are triggered by emphatic feelings of self-identification and real proximity between pro-beneficiaries and vulnerable beneficiaries or (2) trajectories that originate within the French body politic that are triggered by a feeling of Fraternity as understood under republicanism. In the latter case, this type of trajectory must be related to a series of variables that are almost ubiquitous in the scholarly works that look at the interpenetration between citizens and their broader political community (Nie et al. 1996; Parry et al. 1992). In addition to another variable that considers information-seeking through the medium of newspapers, we examine voting and having a general interest in politics: these variables have often been used by scholars, for example, to establish a positive relationship between political interest and voting (Verba et al. 1995) or, on the contrary, to question this relationship (Lassen 2005).

By taking into account the complex relationship between solidarity as an input and as an output, our ultimate aim is to distinguish between on the one hand a "private-individual" (henceforth, individual) solidarity trajectory and on the other hand a "public-republican" (henceforth, political) trajectory. This dual approach to solidarity is also valuable since it allows us to understand the interplay between different citizenship traditions that have developed either through mutual acknowledgement and shared purposes or through access to the policy domain of rule-making (Cinalli 2017). More specifically, the distinction we establish between an individual solidarity trajectory and a political one works as follows. On the one hand, we expect individual variables including self-identification and closeness to vulnerable groups to be especially relevant in the field of disability, owing to the universal sense of responsibility that people for whom solidarity is important can appeal to when they act in support of fellow citizens who often suffer from a disability that neither they nor power holders can be held responsible for. On the other hand, political variables including the internalisation of republican norms are expected to be especially relevant in the field of unemployment, owing to the politically based sense of responsibility that French people can appeal to in support of fellow citizens who are vulnerable as a result of politics, and specifically of unemployment policies and of specific decisions taken by power holders. 
Lastly, the field of refugee assistance provides us with a further opportunity to disentangle the individual and political determinants of solidarity actions. In this case, the main expectation going into the study is that individual variables will prove to be more effective in terms of leading to solidarity actions. Since refugees are not part of the republican community of citizens, the solidarity trajectory leading French nationals to help them should logically be determined by individual rather than by political variables. France often considers itself to be a "civilising power" (Burrow 1986), a country where refugees (and migrants in general) are the objects (rather than the subjects) of politics, at least until they become fully integrated into the republican community of citizens (Schnapper 2003).

Given that both solidarity trajectories are relevant when it comes to support for the disabled, we expect to find a much higher level of solidarity actions in the field of disability than in the other two fields. We expect the individual trajectory to be rather ineffective in the field of unemployment and the political trajectory to be likewise ineffective as a means of triggering support to refugees. This also means that we expect the general level of solidarity actions to be at its lowest in the field of refugee assistance, since self-identification and a feeling of proximity are determinants that are likely to work less well when we have a high number of national respondents being polled about their solidarity with non-national refugees, who represent a much more distant community of equals, compared for instance to the disabled. Furthermore, we also anticipate some important variations in the pattern of solidarity actions in each of the fields considered. We expect individual types of action to prevail in the field of disability and in the field of refugee assistance owing to the greater importance of the individual trajectory in these fields. Conversely, collective forms of solidarity mobilisation are expected to prevail in the unemployment field, since this issue appears at lot more straightforwardly political in its nature.

\section{The Different Repertoires of Solidarity Actions}

As we said earlier, our cross-field comparison of solidarity follows two main steps. We start by analysing the repertoire of solidarity actions carried out by French citizens, in order to examine whether different fields of vulnerability are characterised by different configurations of solidarity actions. We then continue by focusing on intra-field variations in solidarity, in order to examine whether specific forms of action are prevalent in 
each of the fields considered here. This is grounded on scholarly work that has emphasised the necessity to distinguish between the various facets of a varied repertoire of individual action (Teorell et al. 2007); in our study this analysis of individual actions must also include instances where individuals participate in larger, collective forms of mobilisation (Tilly 1978). In particular, we analyse "donating money" and "donating time" as types of solidarity actions that are individually based and less direct while also taking into account actions such as "protesting" and "buying or refusing to buy specific products", which are collective and more direct forms of mobilisation.

The figures in Table 9.1 reflect the relative importance of these four types of solidarity action across the three fields. The large cross-field variations (cf. the totals in first column) clearly show that solidarity actions vary substantially depending on the specific vulnerable groups that they target. Our first important finding is that a large majority of the people in our sample (54.7\% out of 2098 respondents) engage in multiple forms of solidarity action at the same time (as suggested by the fact that the percentages add up to more than $100 \%$ ). The individuals who take part in these actions are particularly mobilised by disability issues, while their level of participation decreases steeply when the focus is on unemployment, and even more so when actions are meant to help refugees. More specifically, Table 9.1 shows that when all variables are combined, $47 \%$ of the individuals in the sample are willing to support the disabled: in this case the most common types of solidarity actions carried out are "donating money" and "donating time", which account for respectively $27 \%$ and $17 \%$ of the actions carried out by the surveyed population. "Buying or refusing to buy specific products" only concerns $12.9 \%$ of the sample, while protest actions

Table 9.1 Overall support and specific forms of solidarity actions per field (in $\%^{4}$ )

\begin{tabular}{llcrlc}
\hline & $\%$ & Protests & $\begin{array}{c}\text { Donating } \\
\text { money }\end{array}$ & $\begin{array}{l}\text { Donating } \\
\text { time }\end{array}$ & $\begin{array}{c}\text { Buying or refusing to } \\
\text { buy specific products }\end{array}$ \\
\hline Disability & 47.6 & 6.6 & 27.4 & 17 & 12.9 \\
Unemployment & 21.8 & 5.2 & 6.6 & 9.4 & 7.4 \\
Refugees & 17.7 & 3.8 & 8.3 & 6.1 & 5.6 \\
Total & 54.7 & & & & \\
& $(2098)$ & & & & \\
\hline
\end{tabular}


such as demonstrations or strikes concern a much tinier proportion of $6.6 \%$.

In the unemployment field, the proportion of people engaging in solidarity actions decreases to $22 \%$ of the total sample. The percentages of people ready to donate time and money reflect the patterns in the disability field, since they also indicate that the participants' repertoire consists primarily of actions that are individual and less direct. Perhaps not surprisingly, it is more common to contribute time rather than money in the field of unemployment, while the opposite is true in the field of disability. This must no doubt be related to the more financially precarious position of the unemployed, who are systematically excluded from the labour market. However, the percentages indicating people's participation in collective and direct forms of solidarity - by means of product boycotts or protestsshow that there is no direct analogy between solidarity for the unemployed and solidarity for the disabled. In particular, contributions of time and money do not clearly prevail over more direct and collective forms of solidarity actions, which together represent nearly $13 \%$. Lastly, we find the smallest percentages of participation in solidarity actions in the field of refugee assistance: fewer than $18 \%$ of respondents stated that they would actively participate in support actions for refugees. $8.3 \%$ of the individuals in the sample said they had donated money, and a smaller proportion (6.1\%) had donated time to help refugees through volunteering. Compared to the fields of disability and unemployment, participation in protest actions represents no more than $3.8 \%$, and buying or refusing to buy specific products concerns $5.6 \%$ of the total sample.

The evaluation of field-specific actions further enhances our understanding of internal, field-related dynamics. In the second phase of our comparative analysis, we have therefore indicated percentages only as a ratio of the total number of people engaging in solidarity actions $(n=1149)$ and no longer as a ratio of the entire sample of interviewed people. In this way, intra-field differences can be tracked more precisely, and it is easier to see the difference between the types of actions that are individually based and less direct (like donating money or time) and those that are collective and that entail direct mobilisation (such as participating in protests or in product boycotts). Overall, the general patterns characterising each of the three fields of vulnerability are confirmed, and we can once more see that solidarity increases as we move from support for refugees to support for the unemployed, and then to support for the disabled. 
These figures also confirm that individuals engage in several types of solidarity actions at the same time.

However, a closer look at field-specific percentages also shows that in the field of disability, individual and indirect forms of action clearly predominate over other forms of action. The latter are practised by almost the entire sample of people who engage in solidarity actions (over 93\%). Individual forms of action also prevail in the field of unemployment, but with a much lower margin. In this case, findings show that a majority of the people in the sample also engage in collective forms of direct mobilisation $(57.5 \%)$. This is more or less in line with the general perception that France is a country where social movements are a pillar of republican citizenship (Sirot 2014). Lastly, as regards refugees, our findings show that this field has the smallest group of people engaged in solidarity actions ( $n=372$, just over a third of those active within the field of disability). Just as in the field of disability, people who help refugees overwhelmingly choose solidarity actions that are individually based and less direct. In fact, this is where we note a significant gap between the individually based and the collectively based repertoire, given that the latter represents two thirds of the former $(53.2 \%$ vs. $81.1 \%$; larger than the same gap in the field of unemployment).

To sum things up, Tables 9.1 and 9.2 confirm that a majority of people in France engage in solidarity actions, with more than $54 \%$ of individuals participating in one or more forms of solidarity to support the disabled, the unemployed, or refugees. The main result to emerge from this analysis consists in the much greater level of participation in solidarity actions in the field of disability than in the other two fields: findings show that support for the disabled is the most frequent expression of solidarity in France, followed by support for the unemployed. Support for refugees stands out by its low level; refugees receive help from fewer than one-fifth of the people in our sample. However, findings also show that each field is

Table 9.2 Individual versus collective repertoire (in \%)

\begin{tabular}{lrcc}
\hline & $N$ & Collective mobilisation & Individual participation \\
\hline Disability & 999 & 40.9 & 93.1 \\
Unemployment & 458 & 57.5 & 73.1 \\
Refugees & 372 & 53.2 & 81.1 \\
Total & 1149 & & \\
\hline
\end{tabular}


characterised by its own, typical repertoire of solidarity. Individual forms of action prevail in the field of disability and, in relative terms, also in the field of refugees (in the latter case, in an overall context of much lower solidarity). By contrast, collective forms of action prevail in the field of unemployment. These first results concerning the amount of solidarity expressed and its repertoire certainly go some way to confirm our expectations. Solidarity expresses itself most strongly in the field of disability, since it brings together both of the trajectories that connect French citizens to the disabled. On the one hand, emphatic feelings of self-identification and proximity-which express themselves most strongly in the case of people who do not enjoy the same good health as the majority of the population-go hand in hand with a high prevalence of individual forms of solidarity actions. On the other hand, since the disabled are themselves citizens, it is logical that their problems should also be seen as issues that concern the whole republican community, hence the high amount of collective forms of solidarity action. Solidarity actions are less common in the field of unemployment. This is also in line with our theoretical framework, since our expectation was that feelings of empathy would not play the same role as in the case of the disabled. Just as expected, the high prevalence of collective types of solidarity actions indicates that unemployment in France tends to be seen as a political matter rather than as andividual one and that the whole republican community is held accountable for the problem. Lastly, solidarity is at its weakest in the case of refugees, which further serves to reinforce our argument. Since their status means that they stand outside the republican community, refugees only benefit from the type of solidarity that springs from a general empathy with human suffering and an ability to see all people as fellow human beings (yet, as said, a much more distant community of equals than fellow citizens).

We can now move on to consider the respective impacts of the individual trajectory and of the political one. Indeed, the results in this section suggest that the links between these trajectories and solidarity actions deserve additional scrutiny. We must therefore pay closer attention to the specific assumptions underpinning these expectations, namely, that each of these two trajectories represents significant predictors of solidarity action in the field of disability, while only one of the two functions as a significant predictor in the other two fields (the political trajectory in the case of the unemployed and the individual trajectory for the disabled). 


\section{EXPLAINING THE Dynamics of SOLIDARITY: INDIVIDUAL Closeness Versus Republican Citizenship}

This section is designed to assess and explain some of the important arguments that have driven our analyses throughout this chapter, namely, that solidarity actions are more likely to result from an individual trajectory or from a political trajectory depending on the specific field of vulnerability under consideration. For example, we have argued that the political trajectory is most likely to have a strong impact in the field of unemployment, which would go a long way towards explaining why we did indeed note the large amount of collective forms of solidarity action in the field of unemployment. And we have argued that the individual trajectory would be a stronger trigger for solidarity actions in the fields of disability and refugees, which would go a long way towards explaining why we did indeed note the extensive prevalence of individual forms over collective forms.

Regression data does show that in all three fields, the individual trajectory proves relevant when the respondent is empathetically concerned by one of vulnerabilities respectively. Two variables have been included in the first regressions: (1) whether or not the respondent belongs to a vulnerable group (the disabled, the unemployed, or foreigners) ${ }^{5}$ and (2) whether the respondent has relatives or friends who are either disabled, or unemployed, or of foreigner origins. The assumption here is that if individuals are themselves affected by these processes, or if they have a close relationship to other people being affected by same processes, then they are also more likely to be actively engaged in solidarity actions in the relevant field. The second trajectory proves to be more relevant when the respondent's mobilisation follows the political prescriptions of the French Republic. In this case, the crucial variables include being interested in politics, being politically active by voting, and following the political debate by regularly reading newspapers. The objective is to understand whether a political trajectory, informed by political participation and interest in public issues, can help to explain cross-field variations in terms of solidarity actions.

Tables 9.3, 9.4, and 9.5 examine in some detail to what extent solidarity actions in each field follow from the individual trajectory. On the basis of the arguments and of the data that have been laid out in the previous sections, we expected this first trajectory to prove much more important when it comes to solidarity with the disabled and with refugees than for 
Table 9.3 Solidarity towards the disabled individual factors

\begin{tabular}{llcl}
\hline & Coefficient & $\begin{array}{c}\text { Standard } \\
\text { error }\end{array}$ & $\begin{array}{l}\text { 95\% Confidence } \\
\text { interval }\end{array}$ \\
\hline $\begin{array}{l}\text { Considers him-/herself as having a } \\
\text { disability }\end{array}$ & 0.0289 & 0.0346 & $-0.0390,0.0969$ \\
$\begin{array}{l}\text { Has family or friends who are disabled } \\
\text { _Cons }\end{array}$ & $0.184^{* * *}$ & 0.0262 & $0.1330,0.2360$ \\
\hline
\end{tabular}

${ }^{* * *} p<0.01,{ }^{* *} p<0.05,{ }^{*} p<0.1$

Table 9.4 Solidarity towards the unemployed individual factors

\begin{tabular}{llcl}
\hline & Coefficient & $\begin{array}{c}\text { Standard } \\
\text { error }\end{array}$ & $\begin{array}{l}95 \% \text { Confidence } \\
\text { interval }\end{array}$ \\
\hline $\begin{array}{l}\text { Declared that he/she was } \\
\text { unemployed }\end{array}$ & -0.052 & 0.0377 & $-0.1269,0.0212$ \\
$\begin{array}{l}\text { Has unemployed family or friends } \\
\text { Cons }\end{array}$ & $0.033^{*}$ & 0.0190 & $-0.0036,0.0709$ \\
\hline
\end{tabular}

${ }^{* * *} p<0.01,{ }^{* *} p<0.05,{ }^{*} p<0.1$

Table 9.5 Solidarity towards refugees individual factors

\begin{tabular}{llll}
\hline & Coefficient & $\begin{array}{c}\text { Standard } \\
\text { error }\end{array}$ & $\begin{array}{l}\text { 95\% Confidence } \\
\text { interval }\end{array}$ \\
\hline $\begin{array}{l}\text { Born in France } \\
\begin{array}{l}\text { Has family, friends, or acquaintances } \\
\text { coming from a different country } \\
\text { Cons }\end{array}\end{array}$ & 0.045 & 0.0407 & $-0.0346,0.1253$ \\
& $0.122 * * *$ & 0.0174 & $-0.0011,0.0673$ \\
\hline
\end{tabular}

${ }^{* * *} p<0.01,{ }^{* *} p<0.05,{ }^{*} p<0.1$

solidarity with the unemployed. Conversely, the second, political trajectory will presumably play a more important role in the field of unemployment. Tables 9.6, 9.7, and 9.8 therefore combine individual and political variables, in order to show to what extent solidarity can be explained by empathy or by a practice of republican citizenship. Finally, the model also relies on control filters, namely, gender, level of education, and age.

Findings show that individuals who are personally affected by disability or who self-identify with the disabled are not more likely to participate in activities to support the disabled than any other individual. However, the 
Table 9.6 Solidarity towards the disabled individual and political factors

\begin{tabular}{llcc}
\hline & Coefficient & $\begin{array}{c}\text { Standard } \\
\text { error }\end{array}$ & $\begin{array}{l}\text { 95\% Confidence } \\
\text { interval }\end{array}$ \\
\hline $\begin{array}{l}\text { Considers him-/herself as having a } \\
\text { disability }\end{array}$ & 0.0353 & 0.0341 & $-0.0315,0.1022$ \\
Has family or friends who are disabled & $0.170^{* * *}$ & 0.0258 & $0.1200,0.2216$ \\
$\begin{array}{l}\text { Voted in the most recent 2012 elections } \\
\text { Reads the newspaper +3 days a week }\end{array}$ & $0.0743^{* * *}$ & 0.0246 & $0.0259,0.1227$ \\
$\begin{array}{l}\text { Considers him- } / \text { herself to be moderately } \\
\text { or very interested in politics }\end{array}$ & $0.076^{* * *}$ & 0.0218 & $0.0831,0.1687$ \\
_Cons & $0.274^{* * *}$ & 0.0236 & $0.0319,0.1205$ \\
\hline
\end{tabular}

${ }^{* * *} p<0.01,{ }^{* *} p<0.05,{ }^{*} p<0.1$

Table 9.7 Solidarity towards the unemployed: individual and political factors

\begin{tabular}{|c|c|c|c|}
\hline & Coefficient & $\begin{array}{l}\text { Standard } \\
\text { error }\end{array}$ & $\begin{array}{l}95 \% \text { Confidence } \\
\text { interval }\end{array}$ \\
\hline Declared that he/she was unemployed & -0.041 & 0.0371 & $-0.1147,0.0311$ \\
\hline Has unemployed family or friends & $0.036^{* *}$ & 0.0186 & $0.0003,0.0735$ \\
\hline Voted in the most recent 2012 elections & -0.008 & 0.0206 & $-0.0488,0.0322$ \\
\hline Reads the newspaper +3 days a week & $0.118 * * *$ & 0.0182 & $0.0830,0.1543$ \\
\hline $\begin{array}{l}\text { Considers him-/herself to be moderately or } \\
\text { very interested in politics }\end{array}$ & $0.097 * * *$ & 0.0188 & $0.0604,0.1344$ \\
\hline _Cons & $0.099 * * *$ & 0.0205 & $0.0592,0.1398$ \\
\hline
\end{tabular}

${ }^{* * *} p<0.01,{ }^{* *} p<0.05,{ }^{*} p<0.1$

Table 9.8 Solidarity towards refugees individual and political factors

\begin{tabular}{llll}
\hline & Coefficient & $\begin{array}{c}\text { Standard } \\
\text { error }\end{array}$ & $\begin{array}{l}\text { 95\% Confidence } \\
\text { interval }\end{array}$ \\
\hline Born in France & 0.054 & 0.0401 & $-0.0246,0.1327$ \\
$\begin{array}{l}\text { Has family, friends, or acquaintances } \\
\text { coming from a different country }\end{array}$ & 0.022 & 0.0171 & $-0.0108,0.0565$ \\
$\begin{array}{l}\text { Voted in the most recent 2012 elections } \\
\text { Reads the newspaper +3 days a week }\end{array}$ & $-0.071^{* * *}$ & 0.0191 & $-0.1090,-0.0340$ \\
$\begin{array}{l}\text { Considers him- } / \text { herself to be moderately } \\
\text { or very interested in politics }\end{array}$ & $0.091^{* * *}$ & 0.0168 & $0.0811,0.1470$ \\
_Cons & 0.061 & 0.0422 & $-0.0214,0.1444$ \\
\hline
\end{tabular}

$* * * p<0.01,{ }^{* *} p<0.05,{ }^{*} p<0.1$ 
second variable of empathy, namely, proximity, does indeed appear to be correlated with solidarity as an output, thus confirming our hypothesis: the individual trajectory is highly relevant when it comes to explaining solidarity actions in support for the disabled.

The integration of political indicators into the survey improves the model's accuracy. In particular, we observe that both an interest in politics and voting have some impact on solidarity actions in the field of disability, while reading the newspaper has a strong impact. The introduction of political variables does not, however, bring into question our expectations. The individual and the political trajectory both stand out as relevant when it comes to explaining variations in terms of solidarity actions within the field of disability. We can conclude that it is when the individual trajectory and the political trajectory combine that we see the highest levels of solidarity actions across the three fields (cf. section "The Different Repertoires of Solidarity Actions").

The incorporation of a number of sociodemographic controls has a limited effect on the results obtained in Tables 9.3 and 9.6. The model proves to be slightly more effective than the earlier ones at explaining solidarity actions in support of the disabled. Table 9.9 shows that age is not a relevant factor when it comes to explaining solidarity as an output. The same is true of the respondents' level of education. The distribution of individuals with university-level education who do not engage in solidarity actions is equivalent that of less educated people who are likewise not active. Similarly, of all those with secondary-level education, 53\% do not participate in disability-related solidarity actions, compared to $46 \%$ who can be qualified as active or engaged in such actions. A similar conclusion can be drawn in terms of gender. The proportion of women who are active and not active is very similar to the proportion of men who fall in both of these categories.

Data for the field of unemployment proves to be quite different from what we have observed for the field of disability. First of all, Table 9.4 establishes a weak negative relationship between self-identification and the decision to engage in solidarity actions. Even though the validity of this interaction may be limited by the small number of unemployed people featured in the sample, it is nevertheless somewhat surprising to observe that four-fifths of the unemployed are not active, with only one-fifth of them actively engaged in actions designed to combat unemployment. The low ratio of participation suggests that other external factors are likely to be relevant, such as social processes of stigmatisation and defeatism, all of 
Table 9.9 Solidarity towards the disabled individual and political factors (controlled)

\begin{tabular}{|c|c|c|c|}
\hline & Coefficient & $\begin{array}{l}\text { Standard } \\
\text { error }\end{array}$ & $\begin{array}{l}95 \% \text { Confidence } \\
\text { interval }\end{array}$ \\
\hline $\begin{array}{l}\text { Considers him-/herself as having a } \\
\text { disability }\end{array}$ & 0.036 & 0.0343 & $-0.0310,0.1035$ \\
\hline Has family or friends who are disabled & $0.171^{* * *}$ & 0.0259 & $0.1204,0.2224$ \\
\hline Voted in the most recent 2012 elections & $0.055^{* *}$ & 0.0267 & $0.0032,0.1081$ \\
\hline Reads the newspaper +3 days a week & $0.127 * * *$ & 0.0218 & $0.0845,0.1701$ \\
\hline $\begin{array}{l}\text { Considers him-/herself to be moderately } \\
\text { or very interested in politics }\end{array}$ & $0.074^{* * *}$ & 0.0231 & $0.0292,0.1199$ \\
\hline Gender & 0.011 & 0.0218 & $-0.0317,0.0540$ \\
\hline Age & $0.001^{*}$ & 0.0007 & $-2.07 \mathrm{e}-07,0.0029$ \\
\hline Level of education & 0.033 & 0.0232 & $-0.0115,0.0794$ \\
\hline _Cons & $0.178^{* * *}$ & 0.0575 & $0.0660,0.2917$ \\
\hline
\end{tabular}

${ }^{* * *} p<0.01,{ }^{* *} p<0.05,{ }^{*} p<0.1$

which have been discussed in the literature (Jahoda et al. 1971; Schnapper 1981; Demazière and Pignoni 1998). When it comes to having a relationship of empathy with unemployed people, figures reveal that the individual trajectory only has a weak impact on solidarity actions, indeed far less influential than in the field of disability. This confirms that individual variables are inadequate in order to explain the variations in solidarity actions in the field of unemployment.

The political variables provide us with further material to explain solidarity actions in the field of unemployment. We observe that the importance of proximity becomes less relevant than before if we add a number of political variables. In particular, both an interest in politics and (especially) reading newspapers have a positive correlation to the choice of engaging solidarity actions. However participating in elections does not appear to increase solidarity towards the unemployed, which reinforces the argument, outlined in several scholarly works, that there is a great distance between traditional politics and the politics of unemployment (Piven and Cloward 1977; Bagguley 1991, 1992).

The use of controlled regressions suggests once more that sociodemographic variables have a low impact. As far as age is concerned, findings show that being young or old makes no difference when it comes to being actively engaged in support actions - as we had already seen in the case of 
disability. The same conclusion can be drawn for educational level. Given that out of the total number of respondents who support the unemployed ( $N=458)$ one-third has finished their secondary education, and twothirds have undertaken higher studies, education appears to have a more important influence than age but nevertheless not a determinant one. The same pattern repeats itself in the case of gender-related indicators, since a similar proportion of men and women engage in solidarity in the field. ${ }^{6}$

To sum things up, Table 9.10 depicts the main drivers behind solidarity towards the unemployed. The most salient indicators in the field refer to the political trajectory. We conclude-in line with our expectations-that solidarity vis-à-vis the unemployed is not best explained by the individual trajectory, but rather by the political trajectory that is rooted within French republicanism.

As regards solidarity, the first individual variable taken into account is the individual's place of birth, which is used here to deduce whether he or she is a refugee or more broadly a migrant. Our findings reveal that French nationals are more likely to engage in solidarity actions to support refugees, compared to both non-nationals and individuals born abroad. However, the relationship between place of birth and solidarity actions only has a limited significance. Following the same logic, an individual who has relatives or friends that are refugees or

Table 9.10 Solidarity towards the unemployed individual and political factors (controlled)

\begin{tabular}{llll}
\hline & Coefficient & $\begin{array}{c}\text { Standard } \\
\text { error }\end{array}$ & $\begin{array}{l}\text { 95\% Confidence } \\
\text { interval }\end{array}$ \\
\hline Declared that he/she was unemployed & $-0.061^{*}$ & 0.0372 & $-0.1345,0.0117$ \\
Has unemployed family or friends & $0.035^{*}$ & 0.0186 & $-0.0005,0.0724$ \\
Voted in the most recent 2012 elections & 0.023 & 0.0223 & $-0.0206,0.0668$ \\
Reads the newspaper +3 days a week & $0.115^{* * *}$ & 0.0181 & $0.0801,0.1512$ \\
Considers him-/herself to be moderately & $0.085^{* * *}$ & 0.0192 & $0.0480,0.1235$ \\
or very interested in politics & & & \\
Gender & $-0.050^{* * *}$ & 0.0181 & $-0.0857,-0.0145$ \\
Age & $-0.002^{* * *}$ & 0.0006 & $-0.0037,-0.0012$ \\
Level of education & 0.005 & 0.0191 & $-0.0320,0.0432$ \\
_Cons & $0.277^{* * *}$ & 0.0488 & $0.1817,0.3735$ \\
\hline
\end{tabular}

${ }^{* * *} p<0.01,{ }^{* *} p<0.05,{ }^{*} p<0.1$ 
migrants will be slightly more inclined to become active in this field. In this case, we find that self-identification seems to play a major role and proximity a minor one for refugee-related solidarity (contrary to what we had observed for disability).

The inclusion of political indicators provides a clearer picture of the mechanisms accounting for solidarity towards refugees (Table 9.11). While voting has a weak relationship to participation in solidarity actions, interest in politics and reading the newspaper come across as relevant explanatory variables. Therefore, we can conclude so far that the political trajectory appears to account more effectively for the choice to engage in solidarity actions. Undeniably, this is the most surprisingly finding of all, which deserves full consideration in our last section, where we deal with the main results of this chapter.

As regards our control variables, they appear to confirm the patterns that emerged from our study of the two previous fields, since educational level, age, and gender do not appear to be essential factors in explaining solidarity towards refugees. Even though younger people have a slightly stronger tendency to become activists, the correlation with age is nevertheless not very significant. In the same way, but with a clearer discrepancy, men appear to be slightly more active than women. In particular, we see that in the sub-samples of men and women, $19 \%$ of the former and $16 \%$ of

Table 9.11 Solidarity towards refugees individual and political factors (controlled)

\begin{tabular}{|c|c|c|c|}
\hline & Coefficient & $\begin{array}{l}\text { Standard } \\
\text { error }\end{array}$ & $\begin{array}{l}95 \% \text { Confidence } \\
\text { interval }\end{array}$ \\
\hline Born in France & 0.045 & 0.0402 & $-0.0335,0.1241$ \\
\hline $\begin{array}{l}\text { Has family, friends, or acquaintances } \\
\text { coming from a different country }\end{array}$ & 0.021 & 0.0171 & $-0.0122,0.0548$ \\
\hline Voted in the most recent 2012 elections & $-0.037^{*}$ & 0.0207 & $-0.0784,0.0028$ \\
\hline Reads the newspaper +3 days a week & $0.111 * * *$ & 0.0167 & $0.0787,0.1443$ \\
\hline $\begin{array}{l}\text { Considers him-/herself to be moderately } \\
\text { or very interested in politics }\end{array}$ & $0.082 * * *$ & 0.0178 & $0.0472,0.1171$ \\
\hline Gender & -0.026 & 0.0167 & $-0.0596,0.006$ \\
\hline Age & $-0.002 * * *$ & 0.0005 & $-0.0035,-0.0012$ \\
\hline Education level & 0.021 & 0.0177 & $-0.0132,0.0565$ \\
\hline _Cons & $0.193 * * *$ & 0.0601 & $0.0758,0.3118$ \\
\hline
\end{tabular}

${ }^{* * *} p<0.01,{ }^{* *} p<0.05,{ }^{*} p<0.1$ 
the latter are activists. Lastly, educational level has a more limited impact here than in the case of unemployment, but a more important influence than in the field of disability. ${ }^{7}$

\section{Conclusion}

This chapter has analysed variations in the pattern of solidarity actions designed to support the disabled, the unemployed, and refugees. These three groups have become increasingly vulnerable in France during the last few years as a result of decreasing social protection and of welfare cuts: the notion that one ought to feel an unconditional solidarity towards the vulnerable has lost its hold, paving the way for a new state approach to "conditional" forms of welfare and protection. As a result, state-run solidarity systems now require the vulnerable themselves to assume ever more responsibility for their problems (Cinalli and De Nuzzo 2017). Against this background of increasing policy restrictions, the present chapter has analysed the bottom-up dynamics of solidarity linking French people to some of most vulnerable groups. The main aim has been to understand which factors are more likely to lead to solidarity actions (this is what we mean by solidarity as an output). In particular, we have focused on two major solidarity trajectories - an individual trajectory and a political trajectory (that is what we mean by solidarity as an input) - with the expectation that both of them would prove important in accounting for variations in the amount and the type of solidarity actions in each of the fields of vulnerability considered here.

What characterises the individual trajectory is that the solidarity actions in which a person chooses to engage (the output) must be understood as a direct consequence of individual variables of empathy, in this case selfidentification and proximity (the input). Conversely, in the political trajectory, solidarity actions (the output) are determined by political variables like voting, having an interest in politics, and keeping abreast of the public debate (the input). We did not, however, expect that both trajectories would always combine in the same way. For example, if one considers the usual argument of social capital scholarship that associations are extremely important since they enable individuals to form human bonds (the individual variables, in our theoretical framework) while also engaging in purposeful political action (the political variables, in our theoretical framework) (Rosenstone and Mark Hansen 1993; Lichterman 2005; Putnam 1993, 2000), this could have prompted us to simplistically assume that both 
trajectories would have worked in synergy for all vulnerable groups. On the contrary, we suspected that for some vulnerable groups, individual bonding could in fact reinforce their self-exclusion from politics ( $\mathrm{cf}$. the notion of "polarisation" in Sunstein 2002). In the case of the unemployed, for instance, self-identification can be hampered by the increasing stigmatisation they face in society at large.

The only field where we expected both trajectories to neatly combine was the field of disability, given that solidarity with the disabled can be triggered by both individual and political variables. We expected that the political trajectory would prevail in the field of unemployment, given that solidarity, in this case, is directed towards fellow citizens penalised by specific policies, but with whom it might not be easy to form bonds (especially in terms of self-identification). Lastly, we expected the individual trajectory to prevail as a driver of solidarity actions for refugees, since the latter can be seen as fellow human beings, but not as fellow citizens since their status places them outside the political community.

Our results did indeed prove that the individual trajectory and the political trajectory combine in various ways and that they can help to account for variations in the amount and forms of solidarity actions across different fields of vulnerability, even when controlling for important sociodemographic factors like age, education, and gender. Among the expectations that were confirmed by our data was the suspicion that the political trajectory was the only possible driver of solidarity actions in the unemployment field. As expected, French citizens who engage with politics and follow the public debate are also more likely to see unemployment as the consequence of certain political choices and of specific policies, which makes it a problem to be solved by calling for collective action and for public solutions. Solidarity actions will therefore be carried out (mainly in a public and collective way) in spite of the processes of stigmatisation that are at work and that weaken the effectiveness of the individual trajectory. By contrast, the individual trajectory plays an important role in the field of disability, where it combines with political variables in a way to lead to the highest level of solidarity actions across all three fields.

However, the main point to emphasise is that results did fall short of our expectations when it came to solidarity towards refugees. While we were initially unsurprised to see that solidarity actions were at their lowest level in this field, and that they were mainly the result of an 
individual and private repertoire, we were quite surprised to discover that solidarity actions were especially tied to political variables. This means that the political trajectory proved to be the one with a relevant impact even in the case of a vulnerable group that falls outside the political community of republican citizens. This result stands out as an important discovery, insofar as it undermines two of the assumptions on which we based our research. One of these was that republican citizenship can only account for solidarity that is acted through a collective, public understanding of political intervention. But manifestly this is not the case given that the political trajectory proves relevant to explain the dynamics of solidarity across all fields of vulnerability, including in fields where the individual and private repertoire prevails significantly over the public and collective repertoire. Secondly, and most importantly, our findings show that in spite of the prevailing culture of disenchantment towards public institutions, people in France remain interested in politics, and, one could say, very republican. The political community cannot be in such bad health in France as pundits and commentators repeatedly claim it is, if republican citizenship appears to be a key mechanism to mobilise people when dealing with vulnerability.

This chapter has focused on the French case, but it has a much broader relevance since it shows that the notion of solidarity is neither simple nor monolithic, and that one should ideally talk not of one, but of several "types of solidarities" to account for the complex articulations of the different trajectories that link solidarity as an input and solidarity as an output. The same can be said for the notion of vulnerability, since we have shown that trajectories of solidarity do indeed change, and quite significantly so, depending on the specific vulnerable group that they target. While our scholarly pride may have been piqued by the discovery that our theoretical framework was not adequate to account for our unexpected results in the field of refugees, as citizens, these results provide us with much to rejoice over. In particular, we have discovered that the political trajectory of solidarity can have a remarkable potential even when it comes to helping vulnerable people outside the boundaries of the political community in France. Or put more simply, republicanism appears, at least this once, to fully live up to its universalist ideals. This may be due to the resilience of French republicanism but also, more broadly, to the fact that the strength of a community of nationals, either in France or elsewhere, can exceed the strict definition of its borders, both in human and in geographic terms. 
The resilience of the French citizenry does not, therefore, necessarily play into the hands of those who increasingly seek to use it as an instrument to further extremist views that preach the rejection of refugees and of nonnational "aliens" in general.

\section{Notes}

1. See, for example, the article entitled "ll October 2013 migrant tragedy: Italians navy officers placed under investigation", The Independent, 23 October 2016, or the article "Stiamo morendo, per favore: le telefonate del naufragio dei bambini", L'Espresso, 9 May 2017.

2. Cf. the article "How Nicolas Sarkozy's father once lived rough in Paris", The Telegraph, 11 April 2009.

3. http://www.connexionfrance.com/social-benefits-student-housing-disability-home-help-cut-income-support-rsa-11820-view-article.html.

4. $N$ sample is 2098 . All variables in the tables were weighted.

5. Self-identification with refugees was assessed through a broader reference to foreigners in general. The assumption was that self-identification and proximity to foreigners and people of foreigner origins provide some strong bases for empathy with refugees.

6. Yet, the effect of sociodemographic variables in the model appears to be relevant, since the impact of self-identification increases, while the importance of voting changes to a positive and slightly more significant one.

7. Once again, the impact of sociodemographic controls on the model proves to be crucial, since they improve the model's accuracy. In particular, including these controls illustrates the impact of all the respective variables. It reduces the negative impact of voting. Since the reading of newspapers and having an interest in politics remain important factors, we are drawn to conclude that the political trajectory stands out as the most important path accounting for support towards refugees.

\section{REFERENCES}

Andersson, L., \& Sundin, E. (2016). Disaster Tourists, Smartphone Bystanders, Mediated Witnesses or Citizen Journalists? Bystander Theories and Mobile Media Practices at Accident Sites (1st ed.). Prague: ECREA.

Arendt, H. (1982). Les Origines du totalitarisme. Paris: Seuil.

Bagguley, P. (1991). From Protest to Acquiescence? Political Movements of the Unemployed. London: Macmillan.

Bagguley, P. (1992). Protest, Acquiescence and the Unemployed: A Comparative Analysis of the 1930s and 1980s. British Journal of Sociology, 43, 443-461. 
Baglioni, S., \& Giugni, M. (2014). Civil Society Organizations, Unemployment, and Precarity in Europe. Basingstoke: Palgrave Macmillan.

Bellamy, R., Castiglione, D., \& Shaw, J. (Eds.). (2006). Making European Citizens: Civic Inclusion in a Transnational Context. Basingstoke: Palgrave Macmillan.

Berend, T. I. (2016). The Contemporary Crisis of the European Union. London: Routledge.

Bourgeois, L. (1896). Solidarité. Paris: A. Colin.

Burrow, M. (1986). Mission Civilisatrice. The Historical Journal, 29(1), 109-135.

Calhoune, C. (2017). Brexit: Sociological Responses, in William Outhwaite. London: Anthem.

Chabanet, D. (2014). Between Youth Policy and Employment Policy: The Rise, Limits and Ambiguities of a Corporatist System of Youth Representation within the EU. Journal of Common Market Studies, 52(3), 479-494.

Chabanet, D. (2017). The Social Economy Sector and the Welfare State in France: Toward a Takeover of the Market? Voluntas, 28(6), 2360-2382.

Cinalli, M. (2004). Horizontal Networks vs. Vertical Networks in MultiOrganisational Alliances: A Comparative Study of the Unemployment and Asylum Issue-Fields in Britain. EurPolCom, 8(4), 1-31.

Cinalli, M. (2017). Citizenship and the Political Integration of Muslims. Basingstoke: Palgrave Macmillan.

Cinalli, M. and C. De Nuzzo (2017). Disability, Unemployment, Immigration: Does Solidarity Matter in Times of Crisis? (French Case). WPI Report for the TransSOL Project, Unpublished Manuscript.

Dainotto, R. (2007). Europe (in Theory). Durham: Duke University Press.

Darley, J., \& Latané, B. (1968). Bystander Intervention in Emergencies: Diffusion of Responsibility. Journal of Personality and Social Psychology, 8, 377-383.

de la Dehesa, G. (2006). Winners and Losers in Globalization. Oxford: Blackwell.

Delhey, J. (2007). Do Enlargements Make the European Union Less Cohesive? An Analysis of Trust Between EU Nationalities. Journal of Common Market Studies, 45(2), 253-279.

Demazière, D., \& Pignoni, M. T. (1998). Chômeurs: du silence à la révolte. Paris: Hachette.

Department of Communities and Local Government. (2015). Statistics. Retrieved May 24, 2017, from https://www.gov.uk/government/organisations/ department-for-communities-and-local-government.

Giugni, M., \& Grasso, M. (2015). Austerity and Protest: Popular Contention in Times of Economic Crisis. Farnham: Ashgate.

Giugni, M., \& Passy, F. (2001). Political Altruism? Solidarity Movements in International Perspective. Lanham, MD: Rowman \& Littlefield Publishers.

Hanagan, M. P. (1980). The Logic of Solidarity: Artisans and Industrial Workers in Three French Towns 1871-1914. Urbana, IL: University of Illinois press. 
Hyman, R. (1986). Reflections on the Mining Strike. Socialist Register, 22, 330-354.

Jahoda, M., Lazarsfeld, P. F., \& Zeisel, H. (1971 [1933]). Marienthal. The Sociography of an Unemployed Community (trans.: Reginall, J., \& Elsaesser, T.). New York: Aldine-Atherton.

Lahusen, C. (2013). The Protests of the Unemployed in France, Germany and Sweden (1994-2004): Protest Dynamics and Political Contexts. Social Movement Studies. Journal of Social, Cultural and Political Protest, 12(1), 1-22.

Lassen, D. D. (2005). The Effect of Information on Voter Turnout: Evidence from a Natural Experiment. American Journal of Political Science, 49(1), $103-118$.

Lichterman, P. (2005). Elusive Togetherness: Church Groups Trying to Bridge America's Divisions. Princeton, NJ: Princeton University Press.

Müller, O. (2009). Analyse critique de la pénalisation du phénomène migratoire en France et en Italie. PhD thesis, Université de Nantes.

Müller, O. (2014). La pénalisation de l'aide au séjour irrégulier: De la volonté politique à la réalité judiciaire. Master's thesis, IEP, 2009. Retrieved May 29, 2017, from http://www.gisti.org/IMG/pdf/Memoire_IEP_olivia_muller_2009.pdf.

Nie, N., Junn, J., \& Stehlik-Barry, K. (1996). Education and Citizenship in America. Chicago: Cambridge University Press.

Parry, G., Moyser, G., \& Day, N. (1992). Political Participation and Democracy in Britain. Cambridge: Cambridge University Press.

Piven, F. F., \& Cloward, R. A. (1977). Poor People's Movements: Why They Succeed, How They Fail. New York: Pantheon Books.

Putnam, R. D. (1993). Making Democracy Work. Civic Traditions in Modern Italy. Princeton, NJ: Princeton University Press.

Putnam, R. D. (2000). Bowling Alone. The Collapse and Revival of American Community. New York: Simon and Schuster.

Rehm, P. (2009). Risks and Redistribution: An Individual-Level Analysis. Comparative Political Studies, 42(7), 855-881.

Rosenstone, S., \& Mark Hansen, J. (1993). Mobilization, Participation, and Democracy in America. New York: Macmillan.

Schnapper, D. (1981). L'épreuve du chômage. Paris: Gallimard.

Schnapper, D. (2003). La communauté des citoyens. Paris: Gallimard.

Siméant, J. (1998). La Cause des Sans-Papiers. Paris: Presses de Science Po.

Sirot, S. (2014). 1884, des syndicats pour la République. Lormont: Le Bord de l'eau.

Stjerno, S. (2012). Solidarity in Europe. The History of an Idea. Cambridge: Cambridge University Press.

Sunstein, C. (2002). The Law of Group Polarization. The Journal of Political Philosophy, 10(2), 175-195. 
Teorell, J., Torcal, M., \& Montero, J. R. (2007). Political Participation: Mapping the Terrain. In J. W. van Deth, J. R. Montero, \& A. Westholm (Eds.), Citizenship and Involvement in European Democracies: A Comparative Analysis. London: Routledge.

Tilly, C. (1978). From Mobilization to Revolution. Reading, MA: Addison-Wesley. Verba, S., Lehman Schlozman, K., \& Brady, H. (1995). Voice and Equality: Civic Voluntarism in American Politics. London: Harvard University Press.

Wilde, L. (2013). Global Solidarity. Edinburgh: Edinburgh University Press.

Open Access This chapter is licensed under the terms of the Creative Commons Attribution 4.0 International License (http://creativecommons.org/licenses/ by $/ 4.0 /)$, which permits use, sharing, adaptation, distribution and reproduction in any medium or format, as long as you give appropriate credit to the original author(s) and the source, provide a link to the Creative Commons license and indicate if changes were made.

The images or other third party material in this chapter are included in the chapter's Creative Commons license, unless indicated otherwise in a credit line to the material. If material is not included in the chapter's Creative Commons license and your intended use is not permitted by statutory regulation or exceeds the permitted use, you will need to obtain permission directly from the copyright holder.

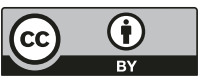

